\title{
Evaluation of Early Maturing Sorghum and Cowpea Varieties Intercropping for Animal Nutritive Value and in vitro Dry Matter Digestibility in Fedis District, Eastern Ethiopia
}

\author{
Wubshet Tesfaye ${ }^{1} \quad$ Tessema Zewdu ${ }^{2} \quad$ Tamado Tana $^{2}$ \\ 1.Fedis Agricultural Research Center, Harar, Ethiopia \\ 2.College of Agriculture and Environmental Sciences, Haramaya University, Haramaya, Ethiopia
}

\begin{abstract}
The shortage of arable land and shortage of livestock feed are major constraints in East Hararghe Zone. Thus, a field study was conducted to evaluate an early maturing sorghum varieties and cowpea genotypes intercropping for both food and feed production at Fedis Agricultural Research Center, eastern Ethiopia in 2018 cropping season. Two cowpea genotypes(lines) (9333 and 9334) were intercropped with three varieties of early maturing sorghum (Teshale, Birhan and Melkam) and compared with sole cropping of all the varieties, which were laid out in a randomized complete block design with three replications. The analyzed result showed the NDF content was significantly different $(\mathrm{p}<0.05)$ among intercropped and sole sorghum the maximum NDF was recorded from sole sorghum Teshale (69.56\%) and the minimum sorghum Birhan + cowpea (9333)(57.75\%) and the Intercropping sorghum improved the CP of sorghum stover mean from sole (5.31\%) to intercropped (6.03\%). the . Cropping systems and cowpea genotypes were significantly affected $(\mathrm{p}<0.05)$ the content of CP and NDF. The maximum CP obtained from cowpea (9334) + sorghum Teshale 29.19\%), and the minimum CP obtained from sole cowpea (9333) (24.38\%). Generally, the results of this study showed that intercropping of sorghum-cowpea were increased the productivity of grain yields and biomass yields of sorghum varieties and it increased nutritional quality of cowpea and sorghum stover. Based on the results of this study, it could be concluded that intercropping sorghum with forage cowpea; preferably sorghum Melkam + cowpea (9333) to be appropriate to increase quality of sorghum stover in the study area.
\end{abstract}

Keywords: Chemical composition, Digestibility and Forage legumes

DOI: $10.7176 / \mathrm{FSQM} / 107-01$

Publication date: April $30^{\text {th }} 2021$

\section{INTRODUCTION}

Ethiopian has a large livestock population and diverse agro-ecological zones suitable for livestock production and for growing diverse types of food and fodder crops. However, livestock production has mostly been subsistenceoriented and characterized by very low reproductive and production performance; those were due to primarily shortages of quality and quantity of animal feed (Maleda, 2013). The constraint of livestock feed due to land degradation, land shortage and poor soil fertility (Tewoderos et al., 2007) and as the result of a rapidly increasing human population pressure, cropping is expanding and grazing areas are shrinking (Adugna, 2007).

Intercropping is a system that has long been practiced by smallholder farmers in various tropical and subtropical regions worldwide Brooker et al. (2016). Intercropping is a potentially beneficial system to mitigate risks associated with crop failure (Kermaha et al., 2017). Cereal-legume intercrops have greater nutrient use efficiency because legume has the ability to fix atmospheric $\mathrm{N}$ and make available to the cereal crop Musa et al. (2012) and hence improve animal nutritional quality of the component crops.

Cowpea is among the most widely used legumes in the tropical world. It can be incorporated into cereal cropping system to address soil fertility decline and cereals to the provision of better legume/stover to cereal (Cook et al., 2005). Compatible companion crops in intercropping systems under limited external inputs could provide a potential productivity and profitability (Yildirim and Guyenc, 2005), and a potential systems to reduce shortage of animal feeds, particularly in areas where cropland is in scarce.

The main objective of the study was

- To evaluate nutritional quality and in vitro dry matter digestibility of sorghum stover and cowpea herbage for animal feed in intercropping and sole cropping systems

\section{MATERIALS AND METHODS}

\subsection{Description of the Study Area}

The study was conducted at Boko substation of Fedis Agricultural Research Center under rain fed condition. The station is found in eastern parts of Ethiopia, which is $550 \mathrm{~km}$ to the East of Addis Ababa and $24 \mathrm{~km}$ southeast of Harari city. The Fedis Woreda is situated at an altitude of 1050 to $2118 \mathrm{~m}$ above sea level, (Fuad et al., 2018). The amount of rainfall varies between 650 and $750 \mathrm{~mm}$, while the average temperature of the Woreda ranges between 25 and $30^{\circ} \mathrm{C}$ (Zenna, 2016). 


\subsection{Description of the Experimental Materials}

Two-cowpea genotypes (9334 and 9333) were used with three varieties of early maturing sorghum (Teshale, Birhan and Melkam) and all the materials were obtained from Fedis Agricultural Research Center. The experimental materials were selected on the basis of their current and potential importance and mainly on their productivity and heights of the plants.

\subsection{Treatments and Experimental Design}

Cowpea and sorghum under sole and intercropping systems were laid out in a randomized complete block design $(\mathrm{RCBD})$ with three replications in a plot area of $(3 \times 3) \mathrm{m}^{2}, 1 \mathrm{~m}$ between plot and $1.5 \mathrm{~m}$ between block. Sorghum was planted at a spacing of $75 \mathrm{~cm}$ between rows $\times 20 \mathrm{~cm}$ between plants for sole and intercropping. Cowpea in intercropping was planted after twenty days of sorghum planting. Cowpea was planted in central rows of sorghum, which was $37.5 \mathrm{~cm}$ far away from sorghum row under intercropping and between sole rows of cowpea. In other words, intercropped cowpea was planted at a spacing of $75 \mathrm{~cm}$ between rows. Sorghum-Cowpea intercropping were planted 1:1(one row of cowpea with one row sorghum) row arrangement as a recommended of Tajudeen and Aliyu (2010) and seed proportion for intercropping 100:100 sorghum + cowpea respectively. The sole and intercropping cowpea were planted in $37.5 \mathrm{~cm}$ between rows and $10 \mathrm{~cm}$ between plants.

Table 1. Treatment arrangements of the crops and seed proportion

\begin{tabular}{clc} 
Treatments & \multicolumn{1}{c}{ Treatment descriptions } & Sowing proportion in \% (cowpea: sorghum) \\
\hline T1 & Cowpea (9334) + Sorghum (Teshale) & 100 \\
T2 & Cowpea (9334) + Sorghum (Birhan) & 100 \\
T3 & Cowpea (9334) +Sorghum(Melkam) & 100 \\
T4 & Cowpea (9333) +Sorghum (Teshale) & 100 \\
T5 & Cowpea (9333) + Sorghum (Birhan) & 100 \\
T6 & Cowpea (9333) + Sorghum (Melkam) & 100 \\
T7 & Cowpea (9334) sole & 100 \\
T8 & Cowpea (9333) sole & 100 \\
T9 & Sorghum(Teshale) sole & 100 \\
T10 & Sorghum (Melkam) sole & 100 \\
T11 & Sorghum (Birhan) sole & 100 \\
\hline
\end{tabular}

\subsection{Experimental Procedure and Field Management}

Land preparation was done at the middle of April with a tractor, harrowed and leveled before planting. The seed rate of $12 \mathrm{~kg} \mathrm{ha}^{-1}$ for sole and intercropping sorghum respectively was planted at row spacing of $75 \mathrm{~cm}$ through drip sowing with $5 \mathrm{~cm}$ deeps when the soil has enough moisture for seed germination. After twenty days, cowpea varieties were planted with the seed rate of $30 \mathrm{~kg} \mathrm{ha}^{-1}$ sole and intercropping, respectively. Application of NPS $\left(19 \% \mathrm{~N}, 38 \% \mathrm{P}_{2} \mathrm{O}_{5}\right.$ and $\left.7 \% \mathrm{~S}\right)$ and Urea $(46 \% \mathrm{~N})$ at $100 \mathrm{~kg} \mathrm{ha}^{-1}$ rate was uniformly applied the time of sorghum planting while urea at the rate of $100 \mathrm{~kg} \mathrm{ha}^{-1}$ was uniformly applied after plants emerged 2-3 leaves. Before urea applicated, thinning should be done to reduce the population of sorghum to normal plant population and weeds were also cleared.

\subsection{Data Collection and Measurement}

\subsubsection{Chemical and nutritional quality parameters of cowpea-sorghum intercropping}

Chemical and quality parameters: five randomly sample plants were taken at $50 \%$ flowering stage for both crops to determine dry biomass yield. The dry biomass weight of the sample taken after partial sun-dried of $150 \mathrm{~g}$ to and then the samples were oven-dried at $65^{\circ} \mathrm{C}$ for 72 hours to determine dry matter yield. The samples were analyzed for Dry Matter (DM), Crude Protein (CP), fiber and Ash at Holetta nutritional laboratory.

Crude protein (CP): nitrogen concentration of sorghum/cowpea was determined by grinding the plant material, its digestion and distillation by micro-Kjeldahl method (AOAC, 1994). The crude protein content was determined as a product of $\mathrm{N}$ x 6.25 (Jackson, 1962).

Fiber: Alternative procedure for fiber which had been developed by Van Soest method (detergent Method) used to determine insoluble cell wall matrix (Van Soest, 1967) such as; Neutral detergent fiber (NDF): which was the residue after extraction with boiling neutral solutions of sodium lauryl sulfate and ethylene-diamine tetra acetic acid, consists mainly of lignin, cellulose and hemicellulose

Acid detergent fiber (ADF): it was the residue after refluxing with $0.5 \mathrm{M}$ sulphuric acid and cetyltrimethylammonium bromide, and represents the crude lignin and cellulose fractions of plant material

Acid detergent lignin (ADL): it was determination involves the preparation of acid detergent fiber as the preparatory step. The ADF was treated with 72 percent sulphuric acid, which dissolves cellulose. Ashing the residue determines crude lignin 
Ash: it was determined by igniting the dried sample in a muffle furnace at $500^{\circ} \mathrm{C}$ overnight and Cool in a desiccator and take weigh.

In vitro dry matter digestibility (IVDMD): it was a laboratory test used as a plant quality index for animal feed by animal nutritionists (Tilley and Terry 1963, Harris 1970). In vitro dry matter digestibility (IVDMD) was analyzed at Holetta Agricultural Research Center. The two-stage Rumen liquor was collected from two ruminally fistulated steer and transported to the laboratory using thermos flask that has been pre-warmed to $39^{\circ} \mathrm{C}$. Rumen liquor was taken in the morning before animals were offered a feed. A duplicate sample $(0.5 \mathrm{~g}$ each $)$ was incubated with $30 \mathrm{ml}$ of rumen liquor in $100 \mathrm{ml}$ test tube in a water bath at $39{ }^{\circ} \mathrm{C}$ for a period of 48 hours for microbial digestion followed by another 48 hours for enzyme digestion with acid pepsin solution. Drying of samples residues was done at $105^{\circ} \mathrm{C}$ for 24 hours. IVDMD was calculated (Jeans and Yolande, 2007)

The sample was then ashed to estimate In vitro OM digestibility as:

$\underline{\mathrm{OM} \text { in the feed- (OM in residue - blank) }} \times 100$

$\mathrm{OM}$ in the feed

Where $\mathrm{OM}=\mathrm{DM}-$ Ash (measured after incineration of feed or residue).

\subsection{Statistical Analysis}

Data were analyzed using the Statistical Analysis Software to perform ANOVA (SAS 9.1) in a randomized complete block design. Means of all treatments were calculated and the difference was tested for significance using the least significant difference (LSD) test at $\mathrm{p}<0.05$ (Gomez and Gomez, 1984).

\section{RESULTS AND DISCUSSION}

\subsection{Chemical and Nutritional Quality Parameters of Cowpea-Sorghum Intercropping}

\subsubsection{Sorghum stover chemical composition and in vitro organic matter digestibility}

There was a significant difference $(\mathrm{p}<0.05)$ among the chemical composition content (Ash and NDF). But none significant of DM, CP and ADF) of sorghum stover due to the effect of cropping systems (under sole and intercropped sorghum-cowpea) and varieties of sorghum showed in (Table 3).

The dry matter content was not significantly different $(\mathrm{P}>0.05)$ in the stover obtained from the intercropping as well as sole sorghum varieties. However, in all treatments, the result of DM\% that obtained higher than $92 \%$, and average dry matter content was $93.04 \%$. This result was indicated that high dry matter obtained when compared with 2012 feed composition table of sorghum stover of (87\%) DM and also most "dry" feeds, such as grains and hays, often have a DM content of around $85 \%$ to $92 \%$. "Wet" feeds, such as silage and wet distiller's grains, typically have a DM content of 25 to 35 percent. Ash in (Table 3) showed that the ash of sorghum Stover was significantly different $(\mathrm{p}<0.05)$ under sole and intercropping of sorghum/cowpea and sorghum varieties. The maximum Ash recorded by sole sorghum of Melkam [(T10, (13.02\%) and followed by sole Teshale and sole Birhan (T9, 11.66\% and T11 11.23\%)] respectively. The minimum obtained from intercropped sorghum stover of Teshale (T4, 9.88\%), (T1, 10.02\%). Intercropping reduced the Ash content of the stover of sorghum. This was due to the additive effect of cowpea intercropping on total forage quality. The result of this finding is in conformity with the finding of Usman (2014) noted that which lablab intercropping increased the DM but decreased the ash content. The crude protein content was not significantly different $(\mathrm{P}>0.05)$ in the stover obtained from the different treatments of sorghum varieties and intercropping. However, it showed in (Table 3) that numerically different among cropping systems and sorghum varieties. The maximum CP recorded by cowpea $(9333)+$ sorghum Birhan (T5), cowpea (9334) + sorghum Birhan (T2) and sole sorghum Birhan T11); (6.81\%, 6.68\% and $6.26 \%$ ) were followed by cowpea (9333) + sorghum Melkam (T6), cowpea (9334) + sorghum Melkam (T3) and sole sorghum Melkam (T10) $(5.96 \%, 5.86 \%$ and $5.11 \%)$ respectively.

The minimum CP obtained from sorghum Stover of sole sorghum Teshale [(T9, $(4.57 \%)$. In general CP that obtained from tested sorghum stover were classified under poor quality animal feeds according to General Forage Quality Standards for Livestock Diets classification, > 19\% prime(the best quality feeds), QS(1)17-19\%, QS(2)14$16 \%$, QS(3) $11-14 \%$, QS(4) $8-10 \%$ and QS(5) $<8 \%$ of CP indicated that the lowest quality. This indicates that when sorghum intercropping with forage cowpea; it numerically improves the quality of sorghum Stover mean under intercropped $(6.03 \%) \mathrm{CP}$ than sole sorghum stover $(5.31 \%)$. This result agreed with the finding of Mergia (2012), the CP content of maize under sown with forage legumes was the higher ranging from 7.2 to $7.3 \%$, while the CP content of Stover from pure stands was the lowest $6.9 \%$ or $69 \mathrm{~g} / \mathrm{kg} / \mathrm{DM}$. Also, this result similar range with Sergio and Shelby (2016) Oregon State University stated that most forage has a range of $4 \%$ to $24 \%$ CP on a DM basis.

The fiber fractions; [acid detergent fiber (ADF), neutral detergent fiber (NDF) and acid detergent lignin $(A D L)]$; the NDF content was significantly different $(\mathrm{p}<0.05)$ in the stover obtained from the intercropping and sole sorghum. The maximum NDF was recorded from sole sorghum Teshale (T9) whereas the minimum NDF of sorghum stover was obtained of sorghum Birhan + cowpea (9333). This may be due to free asses nutrients and solar radiation among the crops. The average NDF of sorghum stover; Birhan (59.16\%) classified under QS (3), 
Melkam stover (64.66) under QS (4) and Teshale Stover (65.56) category under QS(5) or lower (poor) quality animal feeds. The ADF\% of sorghum stover not affected by sorghum-cowpea intercropping and varieties of sorghum. Even if neutral detergent fiber represents the total fiber component of the feedstuff and value consists of all the cell wall contents plus the acid detergent lignin (ADL) contents ADF and ADL was not statistically affected. Also it includes cellulose, hemicelluloses, and lignin, but unlike ADF, it has no bearing on quality and digestibility. The ADF of sorghum stover of [(Birhan (37.54\%) better than Melkam (40.35\%) and Melkam (40.35) better than Teshale (41.86) averagely]. However, sorghum varieties was not affected sorghum stover and under different category based on "General Forage Quality Standards for Livestock Diets" i.e. prime $<40 \%$ (the best quality feeds), QS (1)40-46\%, QS (2) 47-53\%, QS (3) 54-60\%, QS (4) 61-65\% and QS (5) > 65\% of NDF indicated that the lowest quality. Based on this description the result that obtained from varieties were low; because cereals are higher in lignin content than legumes, grass-legumes was decreased the neutral detergent fiber (NDF) and improve the crude protein content, which is important for production of quality forage. Thus lined with Iqbal et al. (2017) sorghum sown 15 days after Soybean in 2-2 row ratio intercropping decrease the neutral detergent fiber (NDF) and improve the crude protein content

Table 2 Chemical composition and in vitro dry matter digestibility of sorghum Stover grown in sole and under sorghum/cowpea intercropping system

\begin{tabular}{lllllllll}
\hline Cropping system & Trts & $\begin{array}{c}\text { DM } \\
(\%)\end{array}$ & $\begin{array}{l}\text { Ash } \\
(\%)\end{array}$ & $\begin{array}{c}\text { CP } \\
(\%)\end{array}$ & $\begin{array}{l}\text { NDF } \\
(\%)\end{array}$ & ADF $(\%)$ & $\begin{array}{l}\text { ADL } \\
(\%)\end{array}$ & $\begin{array}{l}\text { IVOMD } \\
(\%)\end{array}$ \\
\hline Intercropped & T1 & 92.64 & $10.02^{\mathrm{e}}$ & 5.07 & $65.56^{\mathrm{b}}$ & 38.42 & 4.35 & 51.29 \\
Sorghum & T2 & 93.03 & $10.7^{\mathrm{cd}}$ & 6.26 & $59.62^{\mathrm{e}}$ & 37.79 & 4.48 & 51.32 \\
& T3 & 92.39 & $10.65^{\mathrm{d}}$ & 5.56 & $63.54^{\mathrm{cd}}$ & 38.39 & 4.61 & 50.07 \\
& T4 & 93.23 & $9.88^{\mathrm{e}}$ & 4.88 & $64.61^{\mathrm{bc}}$ & 43.25 & 4.71 & 53.12 \\
& T5 & 93.7 & $10.79^{\mathrm{cd}}$ & 6.81 & $57.75^{\mathrm{f}}$ & 37.16 & 4.73 & 50.42 \\
& T6 & 93.58 & $10.66^{\mathrm{d}}$ & 5.95 & $62.98^{\mathrm{d}}$ & 41.3 & 4.99 & 53.4 \\
Sole Sorghum & T9 & 93.01 & $11.66^{\mathrm{b}}$ & 4.57 & $69.56^{\mathrm{a}}$ & 40.91 & 4.58 & 47.61 \\
& T10 & 92.73 & $13.02^{\mathrm{a}}$ & 5.11 & $63.82^{\mathrm{cd}}$ & 41.38 & 4.59 & 49.48 \\
& T11 & 93.07 & $11.23^{\mathrm{bc}}$ & 6.68 & $60.12^{\mathrm{e}}$ & 37.68 & 4.41 & 51.63 \\
\hline CV $(\%)$ & & 1.07 & 1.6 & 1.52 & 0.61 & 0.82 & 1.53 & 1.09 \\
LSD $(0.05)$ & & NS & 0.56 & NS & 1.12 & NS & NS & NS \\
\hline
\end{tabular}

Trts = treatments, $\mathrm{DM}=$ dry matter, $\mathrm{CP}=$ rude protein, $\mathrm{NDF}=$ neutral detergent fiber; $\mathrm{ADF}=$ acid detergent fiber; $\mathrm{IVOMD}=$ in vitro organic matter digestible; $\mathrm{NS}=$ none significant. $\mathrm{LSD}=$ Least significant difference; $\mathrm{CV}=$ coefficient of variance.

In vitro organic matter digestibility of sorghum stover: IOMD sorghum Stover was no a significant difference $(\mathrm{p}>0.05)$ among sorghum varieties and cropping systems. However, numerically both cropping systems and sorghum varieties were affected sorghum stover of IVOMD. The highest IVOMD were recorded of T6 53.4\% under intercropping of cowpea (9333) + sorghum melkam. The lowest IVOMD of sorghum Stover were recorded under sole cropping of sorghum of Teshale (T9) and Melkam (T10) (47.61\% and 49.48\%) respectively. This different was might be mainly due to the stage of maturity of sorghum, because as indicated intercropping was significantly increased days to maturity and reduced ADF among thus sorghum varieties. This was agreed the finding of Njoka et al. (2006) intercropping the grass with lablab there is an increase in crude protein and decrease in ADF and ADL, which increases the IVDMD of the Napier grass. Also this result was higher than the result that reported by Mekuanint and Girma (2017) on the cereal straw and major feed resource in Bale Zone; In vitro DM digestibility aftermath and wheat straw was 40.36 and $41.92 \%$ in Gasera district and 40.78 and $42.22 \%$ in Ginnir district, respectively

\subsubsection{Forage cowpea chemical composition and in vitro organic matter digestibility}

There was a significant difference $(\mathrm{p}<0.05)$ of the chemical composition content CP and NDF among cropping systems and cowpea genotypes. The maximum CP obtained from cowpea (9334) intercropped with sorghum Teshale (T1) and sorghum Melkam (T3) $29.19 \%$ and $28.06 \%$ of dry matter basis; whereas the minimum CP obtained from under sole cowpea (9333) (T8, 24.38\%) and cowpea (9334) (T7, 25.19\%). This might be due cowpea not further exposed to solar radiation and sorghum hiding cowpea form sun shine and winds then decrease the stage of maturity and shattering of the leaves; increased CP. The maximum NDF obtained from sole cowpea (9333) and the minimum was obtained from T1; cowpea (9334) + sorghum Teshale. So intercropping of cowpea-sorghum increased the quality of forage cowpea by increased CP and decreasing fiber content as fiber is considered to be an anti-nutritional factor. This due to intercropping protected the shattering of leaves of cowpea and protein accumulation high in leaves than in steams. Thus result lined with Ahmad et al. (2007b) sorghum-cowpea and sorghum-sesbania produced better results in terms of green forage yield and quality. However, sorghum-cowpea intercropping and varieties of cowpea were not affected among chemical composition like; DM, ash, ADF and IVOMD of cowpea. In (Table 5) the result indicated that the mean was numerically different among cowpea (9334) $(90.85 \%)$ and cowpea (9333) (91.73\%). In general of forage cowpea in both under sole cowpea and intercropping 
of cowpea-sorghum of CP, NDF, ADF, ADL and IVOMD (25.89\%, 44.6\%, 24.43\%, 2.92\% and 61.09\%) respectively. Thus result indicated that tested cowpea genotypes were categories under prime quality $>19 \% \mathrm{CP}$, $1^{0}$ quality NDF $40-46 \%$, prime quality $\mathrm{ADF}<31 \%$ and $2^{0}$ quality IVOMD $58-61 \%$ respectively according to "General Forage Quality Standards for Livestock Diets" so the result indicated that forage cowpea was highest quality forage.

This result disagreed with the result that reported by Solomon and Kibrom, (2014) Humera, Ethiopia Ash content of cowpea genotypes a mean of $14.2 \%$, Crude protein a mean of $18.1 \%$. In vitro dry matter digestibility $57.3 \%$. This result average ADF content was $53 \%$ with the average NDF content was $58.1 \%$ among genotypes. ADL mean of $13.1 \%$. This variation might be due to seasonal variation, soil types, and the difference between main crops and stages of the plants during the sample taken.

Table 3. Chemical composition and in vitro dry matter digestibility of forage cowpea grown in sole and under sorghum/cowpea intercropping system

\begin{tabular}{lllllllll}
\hline Cropping system & Trts & DM $(\%)$ & $\begin{array}{l}\text { Ash } \\
(\%)\end{array}$ & CP $(\%)$ & $\begin{array}{l}\text { NDF } \\
(\%)\end{array}$ & ADF (\%) & ADL $(\%)$ & $\begin{array}{l}\text { IVOMD } \\
(\%)\end{array}$ \\
\hline Intercropped & T1 & 91.6 & 8.93 & $29.19^{\mathrm{a}}$ & $40.95^{\mathrm{e}}$ & 24.15 & 2.73 & 60.78 \\
Cowpea & T2 & 90.63 & 9.74 & $27.38^{\mathrm{bc}}$ & $42.65^{\mathrm{de}}$ & 24 & 2.99 & 61.47 \\
& T3 & 90.65 & 9.1 & $28.06^{\mathrm{ab}}$ & $42.63^{\mathrm{de}}$ & 23.83 & 3.01 & 60.82 \\
& T4 & 90.66 & 8.41 & $25.88^{\mathrm{cd}}$ & $45.51^{\mathrm{bc}}$ & 24.66 & 2.91 & 61.29 \\
& T5 & 90.6 & 8.93 & $25.38^{\mathrm{d}}$ & $43.93^{\mathrm{cd}}$ & 24.15 & 2.73 & 60.78 \\
& T6 & 90.55 & 8.91 & $25.44^{\mathrm{d}}$ & $44.13^{\mathrm{cd}}$ & 24.16 & 2.8 & 61.15 \\
sole cowpea & T7 & 90.58 & 8.58 & $25.19^{\mathrm{d}}$ & $46.53^{\mathrm{ab}}$ & 26.32 & 3.35 & 60.72 \\
& T8 & 90.65 & 6.83 & $24.38^{\mathrm{d}}$ & $47.89^{\mathrm{a}}$ & 24.14 & 2.84 & 61.71 \\
\hline CV (\%) & & 1.52 & 1.96 & 2.24 & 2.79 & 2.53 & 0.96 & 1.21 \\
LSD & & NS & NS & 1.73 & 1.87 & NS & NS & NS \\
\hline
\end{tabular}

Trts =treatments, T1=Cowpea (9334) + Sorghum (Teshale); T2 = Cowpea (9334) + Sorghum (Birhan); T3 = Cowpea (9334) +Sorghum (Melkam); T4 = Cowpea (9333) +Sorghum $($ Teshale) T5 = Cowpea (9333) + Sorghum (Birhan); T6 = Cowpea (9333) + Sorghum (Melkam), T7=Cowpea (9334) sole, T8=Cowpea (9333) sole, DM= dry matter; $\mathrm{CP}=$ crude protein; $\mathrm{NDF}=$ neutral detergent fiber; $\mathrm{ADF}=$ acid detergent fiber, $\mathrm{ADL}=$ acid detergent lignin, IVOMD = in vitro organic matter digestibility; LSD = least significant difference; $\mathrm{CV}=$ coefficient of variation

\section{ACKNOWLEDGMENTS}

I would like to express my deepest gratitude to Prof. Tessema Zewdu, my major advisor, for his guidance, technical advice, material support, supervision, suggestions and constructive ideas, I am greatly indebted to my Co-advisor Prof. Tamado Tana who provided guidance, and comments on the proposal and thesis write up.

The efforts of all members of Animal Nutrition and Rangeland management team especially Tolera Fikadu and Worku Bekuma were unforgettable. I would like to thank Oromia Agricultural Research Institute for giving me the chance of pursuing this study

\section{REFERENCES}

Adetiloye, P.O., Ezedinma, F.O.C. and Okigbo, B.N. 1983. land equivalent coefficient (LEC) concept for the evaluation of competitive and productive interactions in simple to complex crop mixtures. Ecological Modelling, 19(1): 27-39.

Adugna Tolera. 2007. Feed resources for producing export quality meat and livestock in Ethiopia. Ethiopia Sanitary and Phytosanitary Standards and Livestock and Meat Marketing project (SPS-LMM). 77

AOAC (Association of Official Analytical chemists). 1994. Official methods of analysis 12th ed. Washington. DC

Brooker, R.W., A.J. Karley, A.C. Newton, R.J. Pakeman, C. Schöb. 2016. Facilitation and sustainable agriculture: a mechanistic approach to reconciling crop production and conservation. Function of Ecologies. 30(1): 98107.

Cook, D.R., Zhu, H., Choi, H.K. and Shoemaker, R.C. 2005. Bridging model and crop legumes through comparative genomics. Plant physiology, 137(4):1189-1196.

Dhima, K.V., A.S. Lithourgidis, I.B. Vasilakoglou, and C.A. Dordas. 2007. Competition indices of common vetch and cereal intercrops in two seeding ratio. Field Crops Research, 100: 249-256.

Fuad Abduselam, Samuel Tegene, Zeleqe Legese, Fikadu Tadesse, Alemayehu Biri and Taye Tessema. 2018. Evaluation of Early Maturing Sorghum (Sorghum bicolor(L.)Moench) Varieties, for Yield and Yield Components in the Lowlands of Eastern Hararghe. Asian Journal of Plant Science and Research, 8(1):40-43

Hauggaard-Nielsen, H. \& Jensen E. 2001. Evaluating pea and barley cultivars forcomplementarity in intercropping at different levels of soil N availability. Field Crops Research, 72(3): 185-196.

Iqbal M. 2018. Comparative performance of forage cowpea accessions as companion crops with sorghum under 
varied harvesting times. Bragantia, 77: 476-484. http://dx.doi. org/10.1590/1678-4499.2017247

Jackson, M.L. 1962. Soil Chemical Analysis. Constable \& Co. Ltd. London4, UK.

Maleda Birhan. 2013. Role of Seeding Rates and Cutting Stages on Yield and Quality of Forage Intercropping in the Case of North Gondar, Ethiopia, LAP, LAMBERT Academic Publishing, Germany, ISBN: 978-3-65925690-5-1.

Mead, R. and Willey, R.W. 1980. The concept of a 'land equivalent ratio and advantages in yields from intercropping.Experimental Agriculture, 16:217-228.

Mekuanint Gashaw and Girma Defar. 2017. Livestock feed resources, nutritional value and their implication on animal productivity in mixed farming system in Gasera and Ginnir Districts, Bale Zone, Ethiopia. International Journal of Livestock Production, 8(2):12-23

Musa, E.M., Elsheikh, E.A., Mohamed Ahmed, I.A. and Babiker, E.E., 2011. Intercropping sorghum (Sorghum bicolor L.) and cowpea (Vigna unguiculata L.): effect of Bradyrhizobium inoculation and fertilization on minerals composition of sorghum seeds. ISRN Agronomy

Solomon Gebreyowhans and Kibrom Gebremeskel. 2014. Forage production potential and nutritive value of cowpea (Vigna unguiculata) genotypes in the northern lowlands of Ethiopia. Journal of Agricultural Research and Development, 5(4): Available online http://www.e3journals.org

Zenna T. 2016. Business and management consultancy (TZBMC), CARE ABDISHE/linking initiatives, stakeholders to achieve gender-sensitive livelihood security (LINKAGES) project end line evaluation report 